\title{
基于整合证据链的中草药肝毒性客观辨识与 合理用药：以何首乌为例
}

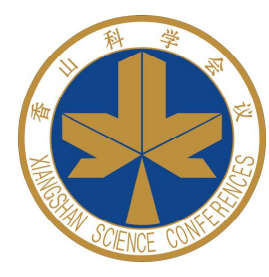

王伽伯 ${ }^{(1)}$ ，李春雨 ${ }^{(12)}$ ，朱云 ${ }^{(4)}$ ，宋海波 ${ }^{3}$ ，柏兆方 ${ }^{(1)}$ ，肖小河 ${ }^{(4 *}$

(1) 解放军 302 医院全军中医药研究所, 北京 100039 ;

(2) 中国医学科学院中国协和医科大学药用植物研究所, 北京 100193;

(3) 国家食品药品监督管理总局药品评价中心, 北京 100045;

(4) 解放军 302 医院中西医结合诊疗与研究中心, 北京 100039

* 联系人, E-mail: pharmacy302@126.com; wjb0128@126.com

2015-11-17 收稿, 2016-02-25 修回, 2016-02-26 接受, 2016-03-23 网络版发表

国家公益性行业科研专项(201507004-04)、国家“重大新药创制”科技重大专项(2015ZX09501004-001-008)和北京市自然科学基金(7152142) 资助

摘要近年来中草药毒副作用尤其是肝毒性的问题频现报道, 尤其是一些传统不认为有毒的中药，如何首乌的 肝损伤(事件)报道, 一度引起民众、媒体、政府和学界激烈讨论. 由于缺少特异性诊断指标, 药物性肝损伤的准确 诊断仍然是国际性难题; 而直于中草药组成和临床用药的复杂性, 中草药肝毒性辨识和临床确诊更加困难, 常存 在误诊. 目前, 符合中药特点的肝毒性客观辨识和诊断方法及规范还几乎是一个空白, 成为制约中药安全用药和 学科发展的关键瓶颈问题. 为此, 本文以热点关注的中药何首乌为例, 提出构建基于整合证据链的中药肝毒性客 观辨识的策略和方法, 进一步从易感人群篎查、炮制减毒、配伍减毒及辨病用药减毒等关乎临床合理用药的问题 进行系统分析, 以期为科学评价中药肝损伤风险、构建合理用药保障技术体系提供研究思路和方法学参考.

关键词中药, 何首乌, 肝毒性, 整合证据链, 客观辨识, 合理用药

近年来, 随着中草药及相关产品的广泛应用, 我 国药品不良反应监测体系的不断完善以及消费者维 权意识的不断提高, 有关中药不良反应(事件)特别是 肝损伤的报道呈明显升高趋势 ${ }^{[1]}$. 直于中草药 “天然 无毒” 的传统观念, 常出现民众为了滋补、保健、养 生随意应用中草药的现象. 由于缺少医生指导和辨 证用药, 加之一些中草药产品存在质量问题, 一些传 统不认为有毒的中药出现不良反应(事件)报道, 如在 美国国家医学图书馆发布的LiverTox肝毒性药物数 据库收载了何首乌、柴胡、淫羊蕉等30多种中药, 引 起国内外广泛关注 ${ }^{[2]}$.

目前药物性肝损伤(Drug-induced liver injury,
DILI)的临床诊断主要是采用Roussel Uclaf Causality Assessment Method(RUCAM)评分系统和结构化专家 意见诊断系统 (Structured Expert Opinion Process,

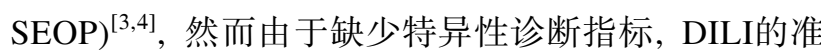
确诊断仍然是国际性难题; 而固于中草药组成和临 床用药的复杂性, 中草药肝损伤(Herb-induced liver injury, HILI)的临床确诊更加困难. 回顾分析HILI相 关临床文献，相当部分的病例缺少直接和确丵的客 观证据，其诊断结果仅为“可能”[5,6]，准确度和可信 度高的HILI临床诊断并不多. 此外, 由于影响中草药 肝毒性的混杂因素众多 ${ }^{[7,8]}$, 比如部分中草药药名混 淆(三七和土三七)、质量参差不齐导致中草药混伪劣

\footnotetext{
引用格式: 王伽伯, 李春雨, 朱云, 等. 基于整合证据链的中草药肝毒性客观辨识与合理用药: 以何首乌为例. 科学通报, 2016, 61: 971-980 Wang J B, LI CY, Zhu Y, et al. Integrated evidence chain-based identification of Chinese herbal medicine- induced hepatotoxicity and rational usage: Exemplification by Polygonum Multiflorum (He shou wu) (in Chinese). Chin Sci Bull, 2016, 61: 971-980, doi: 10.1360/N972015-01289
} 
品存在, 有毒物质污染、与西药联合应用造成 HILI“冤案”、“错案”的发生, 中草药成分复杂、多为 复方配伍导致中草药肝毒性机制难以阐释明确, 另 外个体特异体质的差异等因素, 均导致HILI临床确 诊尤为困难. 特别是目前HILI临床诊断过程中, 极少 病例详细记载导致肝损伤的中草药组成、来源、剂量 等资料, 几乎未对这类中草药进行生药学鉴定, 导致 HILI误诊更易发生, 难以确定致病药源 ${ }^{[9]}$. 当前国际 上DILI诊断方法对HILI的诊断特异性和准确性不高, 故HILI诊断方法不能照搬西药; 而专门针对 HILI特 点的客观诊断方法及规范还几乎是一个空白, 极大地 限制了中药肝毒性客观辨识、科学研究和合理用药.

为此, 本文以近年肝损伤报道和关注较多的中 药何首乌为例, 剖析何首乌肝损伤的客观真实性和 影响要素, 反思中药毒性辨识、评价、风险评控及合 理制用研究的误区和问题, 提出构建基于整合证据 链的中药肝毒性客观辨识的策略和方法, 进一步从 易感人群篮查、炮制减毒、配伍减毒及辨病用药减毒 等关乎临床合理用药的问题进行系统分析, 以期为 科学评价中药肝损伤风险、构建合理用药保障技术体 系提供研究思路和方法学参考.

\section{1 中药何首乌肝损伤研究现状及问题}

何首乌为蓼科植物何首乌Polygonum multiflorum Thunb. 的干燥块根, 生首乌解毒、消痛、截症、通便, 制首乌补肝肾、益精血、乌须发, 传统不认为是有毒 的中药. 然而, 近年来国内外有关何首乌及其制剂肝 损伤不良反应的报道逐渐增多, 包括服用生首乌、制 首乌、含何首乌的复方、中成药或保健食品等. 我国 以及韩国、日本、新加坡、英国等文献报道有关何首 乌肝损伤病例 180余例 ${ }^{[10 ~ 19]}$. 国家不良反应中心收到 的有关何首乌及其制剂的不良反应报告(以肝损伤为 主)近万份. 美国国家医学图书馆发布的LiverTox肝 毒性药物数据库对何首乌进行了专题记录 ${ }^{[2]}$. 2006年 英国、澳大利亚和加拿大药监部门先后发布了何首乌 肝损伤警告信息; 2006年、2013年和2014年我国药监 部门也多次发布了含首乌制剂肝损伤警示和监管通 告. 社会上甚至有 “千年何首乌, 今朝肝毒性”的䇯听 危言, 何首乌肝毒性的问题引起国内外高度关注. 那 么, 以何首乌为代表的中药肝损伤的客观性如何? 发生比例有多大? 有哪些影响因素? 临床上如何科 学安全地使用? 这些问题还缺少科学的审视和研究.
何首乌集中反映了中药肝损伤研究面临的问题 和困境.

首先, HILI在临床诊断方法学方面尚存在较大局 限: HILI的诊断主要依据患者主诉和临床排除性检 查, 缺少特异性指标; 没有专门针对 HILI的诊断指 南, 简单参照国外DILI诊断指南, 对HILI复杂性特点 考虑不足; 临床有时存在“非西药，即中药”的片面性 诊断倾向; 诊断结论缺少临床-实验室完整证据链的 支持. 这些临床诊断方法学的问题导致高质量的中 药肝损伤临床证据不足, 极大地限制了中药毒性的 客观科学评价, 使得关于中药安全性的讨论时常陷 人主观性论战而偏离了科学.

其次, 在中药用药风险评价和控制方面尚存在 较大局限: 在中药用药风险评控过程中, 大多拘泥于 西药毒理学认知模式, 即发现中药含有毒性成分一 笁选毒性靶标一推测毒性效应一提出警戒或封杀中 药, 由于缺少客观可信的临床证据, 在很大程度上放 大了中药毒副作用; 关注所谓高精尖的毒性评价方 法, 对传统中药毒性理论、减毒方法和手段如配伍禁 忌、炮制减毒、配伍减毒、辨证用药减毒等重视不足, 而这些经验和方法在长期临床实践中已被证实是行 之有效的用药风险控制手段; 主要从“药”出发, 很少 从“人”出发, 对机体状态、基础疾病和遗传差异等重 视不足, 缺少从临床中药学和个体化用药人手的风 险控制手段的研究.

因此, 要降低中药肝损伤风险、提高临床用药安 全，应以临床客观证据为核心，在临床诊断方法和用 药风险控制两个方面进行创新性研究, 构建符合中 医药特点的毒性评价与合理用药技术体系, 也即构 建基于整合证据链的中药肝毒性客观辨识与合理用 药研究模式和方法, 从毒性评价到减毒研究、从生物 标志物发现到质量控制开展系统研究(图1), 客观评 价中药肝损伤临床风险，篮查中药特异质肝损伤易 感人群, 厘清影响中药安全用药的因素, 构建中药合 理用药保障技术体系和质量控制标准，从而最终提 高中药安全用药水平.

\section{2 基于整合证据链的中药何首乌肝毒性客 观辨识}

建立符合中药特点的临床客观诊断方法, 是中 药肝损伤研究首先需要解决的问题. 由于在临床上 影响中药相关肝损伤的混杂因素众多、缺少特异性诊 


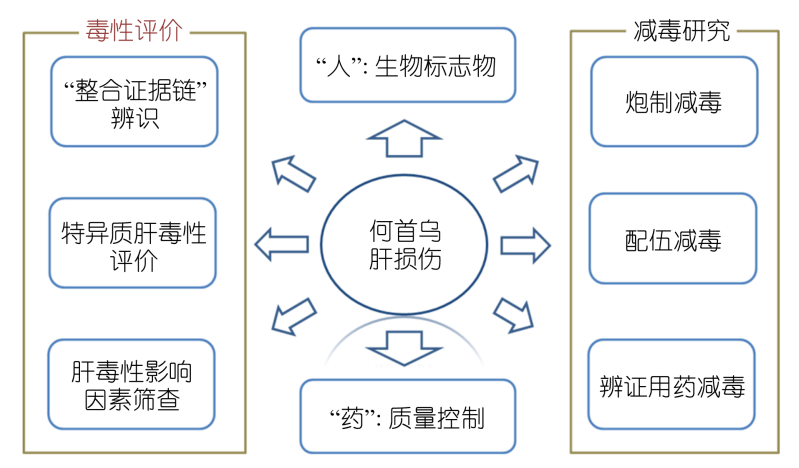

图 1 (网络版彩色)中药(何首乌)肝毒性客观辨识与合理用药研究 思路

Figure 1 (Color online) Investigation strategy for the objective identification and rational uses of CHMs (He shou wu)

断指标, 仅凭临床主观经验就做出中药肝损伤的诊 断, 往往会出现证据力不足甚至误诊的情况. 因此, 整合临床指标、服药史、生药学、生物标志物等多方 面的证据、形成证据链, 将极大地提高中药肝损伤诊 断的准确性和可靠性. 获得的证据链越长、越完整, 诊断的证据力和可靠性越高. 中药肝损伤诊断的证 据力金字塔如图2所示.

基于中药肝损伤诊断证据力金字塔, 课题组首 次提出构建基于整合证据链的中药肝损伤客观辨识 模式和方法：(1) 将肝损伤药源的生药学鉴定纳人 HILI诊断中, 将临床医师的主观经验与损肝中药的 质量安全分析结合起来, 使得HILI诊断更加客观真 实, 避免了HILI诊断的随意性、主观性. (2) 将HILI 诊断分为诊断HILI、排除HILI、不明药源DILI三种情 况, 其中不明药源DILI包括中西药联合应用和不能 获得损肝中药的患者, 将这类患者诊断作为不明药 源DILI有利于提高HILI诊断的客观性和科学性, 在

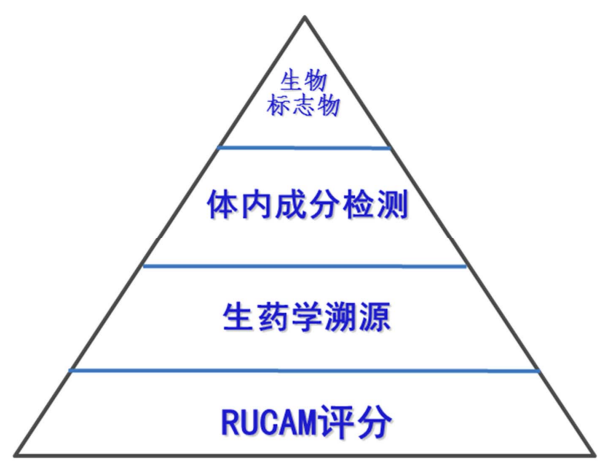

图 2 (网络版彩色)中药肝损伤诊断证据力金字塔 ${ }^{[0]}$

Figure 2 (Color online) Evidence pyramid for diagnosis of HILI
后期研究中对这类肝损伤药源进行追踪观察. (3) 将 文献检索和专家意见列入 HILI诊断系统中, 进一步 考察中药与肝损伤的相关性, 提供HILI更加完整的 证据(图3). 基于整合证据链的中药肝损伤临床诊断 策略和方法, 得到业内专家认可并形成专家共识, 即 将由中华中医药学会发布实施，为HILI的正确诊断 提供完整的临床证据, 为后期HILI机制研究和防治 方案制定提供坚实的基础，也为中药肝毒性研究提 供确切前提和研究方向, 是提高中药临床安全应用 水平的必要举措.

“是药三分毒”, 无论是中药还是西药都具有效、 毒双重作用, 即在治病同时可能产生毒副作用. 在对 待中药何首乌肝毒性的问题上, 既不能回避、更不能 盲目夸大其毒性，造成一叶障目的宣传效应. 事实 上，与何首乌肝损伤报道数相比，服用何首乌的人群 数目更为巨大, 服用何首乌引起肝功能异常的患者 比例很低; 此外, 还有一些何首乌致肝损伤患者是由 于服用存在质量问题的首乌产品，如未有效炮制减 毒、外来有害物质污染等, 或未在医生指导下超适应 症、超剂量、超疗程服药等不合理用药引起的 ${ }^{[9,20]}$, 属 于不良反应事件.

基于整合证据链的中药肝损伤客观诊断策略和 流程, 课题组根据文献病例报道以及对国家药品不 良反应监测中心、解放军 302 医院药物性肝损伤病例 的回顾性分析, 从2035例药物性肝病患者中篮选得 到158例发病前有何首乌及其制剂应用史的DILI患 者. 通过系统排除易混淆诊断肝病、排除联合应用具 有肝毒性西药、排除伪品、重金属/农残/真菌毒素污 染等因素, 结合生药学鉴定, 最终明确由单味何首乌 导致的肝损伤仅 15 例 (占全部疑似病例的 $9.5 \%$ ). 另外 $58.2 \%$ 同时联合应用其他有潜在肝毒性的西药以及其 他由含何首乌但难以确定准确处方的复方导致, 把 这些有混杂因素的病例都笼统认为是何首乌导致的 肝损伤是不准确的; 而其他常见可致肝损伤的化学 药如对乙酰氨基酚、阿奇霉素等抗生素致肝损伤病例 均超过何首乌 ${ }^{[5]}$. 上述结果表明，何首乌肝损伤病例 客观存在, 但总体比率显著低于常见可致肝损伤的 化学药; 并且何首乌肝损伤未见剂量、用药时间与发 生率的明显关联，具有特异质肝损伤特点; 其他影响 因素包括炮制、配伍、服药方式是否合理等. 因此，何 首乌及其制剂总体上是相对安全的, 可能存在特异 质体质的易感人群. 


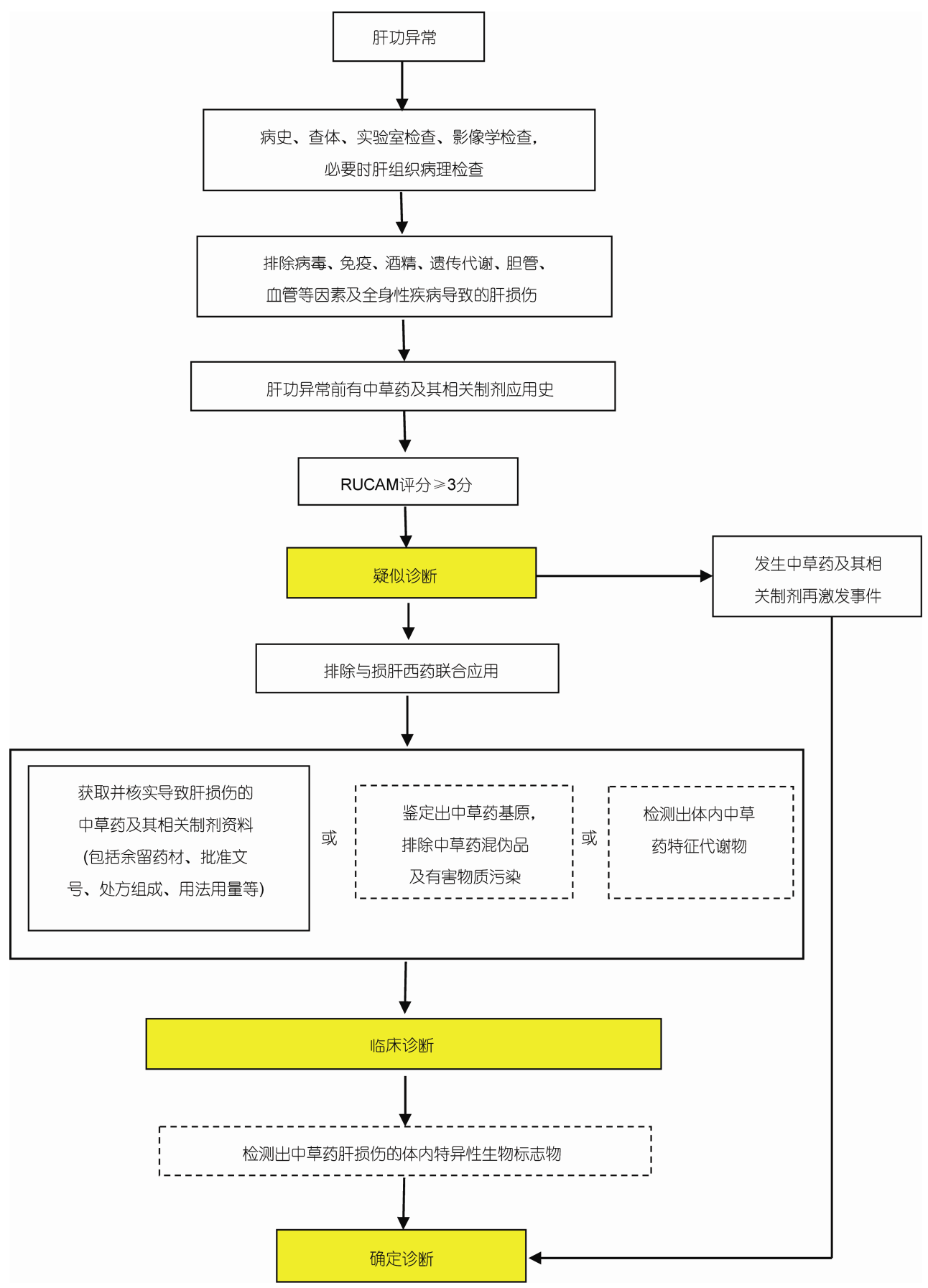

图 3 (网络版彩色)基于整合证据链的HILI诊断策略和流程

Figure 3 (Color online) Integrated evidence chain-based diagnosis strategy and flowchart for HILI

\section{3 中药何首乌合理用药减(避)毒方法体系}

建立符合中药特点的合理用药减(避)毒方法体 系, 是中药肝损伤研究和保障临床安全用药需要重 点解决的问题. 中医药理论中有很多减(避)毒的理论 和措施(见图4), 研究较多的是炮制减毒和配伍减毒,
课题组近年来研究证实辨证用药减(避)毒也是中药 合理制用和安全用药的重要手段 ${ }^{[21]}$.

\section{1 何首乌炮制减毒评价及合理制用}

固固于传统毒性理论“未标毒即无毒”的错误理 念, 导致普遍认为何首乌是无毒的中药. 事实上, 何 


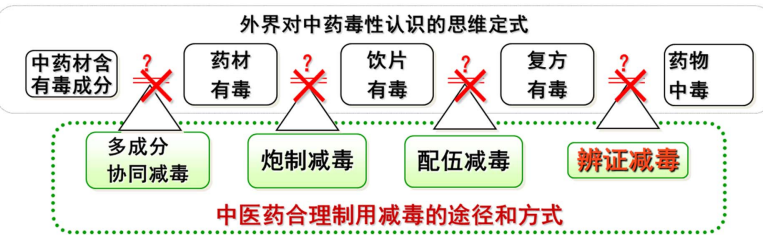

图 4 (网络版彩色)中医药合理制用减毒手段

Figure 4 (Color online) Rational processing and using approaches for alleviating toxicity of CHMs

首乌有生首乌和制首乌之分, 早在《本草汇言》中就 有记载“生用气寒、性敛、有毒; 制熟气温无毒”; 《本 草便读》也记载“大抵生用则流利, 制用则固补”. 故 历代医家均强调炮制入药, 古籍中共记载了蒸制、加 辅料制、不加辅料制等约20余种炮制方法 ${ }^{[22]}$, 如明代 《本草纲目》、清代《成方切用》载有“黑大豆拌九蒸 九曝”法, 我国药典沿用的是蒸制和加辅料黑豆蒸制. 现代研究表明采用黑豆汁炮制, 高压清蒸, 常压清蒸 等炮制方法, 确实能够减弱何首乌的肝细胞毒性作 用, 达到炮制减毒的目的. 课题组在免疫应激模型 上, 临床最大安全治疗剂量由 $1.08 \mathrm{~g}$ 生药 $/ \mathrm{kg}$ (相当于 何首乌生品 $6 \mathrm{~g}$ /日临床剂量的2倍等效剂量)提高到 $8.64 \mathrm{~g}$ 生药 $/ \mathrm{kg}$ (相当于何首乌炮制品 $12 \mathrm{~g}$ /日临床剂量 的8倍等效剂量), 证明何首乌通过炮制后毒性降低 了4倍, 炮制可以达到减毒的目的 ${ }^{[23]}$. 然而, 现在一 些厂家因为利益驱使, 经常不按法炮制, 出现何首乌 饮片炮制不规范或不合格的现象，更甚者有不法厂 家采用墨汁或染料浸泡、代替蒸制的现象 ${ }^{[24,25]}$, 增大 了首乌发生中毒反应的风险. 课题组采用正常人肝 细胞系L02细胞的毒价检测试验，对市售22批制首乌 肝细胞毒价差异进行检测, 有 11 批制首乌毒性大于 生首乌对照药材, 说明没有有效地炮制减毒 ${ }^{[26]}$; 但 是, 这些未炮制减毒的制首乌样品经检测大多符合 目前《中国药典》质量标准. 因此, 非常有必要建立 能够反映首乌炮制减毒程度的质量控制方法和标准, 保证饮片质量, 避免临床用药风险的发生. 针对这一 问题, 课题组首次建立何首乌炮制质量的生物毒价 评控方法 ${ }^{[27]}$.

此外, 目前中药毒性的现代研究基础较为薄弱, 对传统中药炮制技术的继承整理和科学研究不够重 视, 何首乌 “炮制减毒” 的科学性还不够清楚. 古籍中 记载的炮制方法均很复杂, 如加辅料炮制就有很多 种, 如米泔水制、豆制、甘草制、大束制、牛乳拌蒸 等, 加不同辅料炮制的科学内涵尚需要深人的科学
研究. 《药性解》记载首乌“畏猪羊血”“忌铁器”, 《本 草汇言》言何首乌 “一近铁器, 其毒愈酷”, 提示铁会 增强何首乌毒性, 可能与何首乌中二苯乙烯苷遇到 铁离子或亚铁离子生成氧化聚合产物有关 ${ }^{[28]}$. 因此, 非常有必要在挖掘传统中药炮制技术的宝贵经验, 采用现代科学技术阐明首乌炮制减毒的科学原理和 机制, 建立可反映减毒程度的质量评控方法和标准, 避免炮制加工不当, 最大限度降低何首乌临床应用 肝损伤等毒副反应的发生.

\section{2 何首乌配伍减毒评价及合理用药}

中药配伍是中医临床用药的特色优势, 通过合 理的配伍, 调其偏性, 制其毒性, 即能全面照顾病 情, 增强疗效; 又能减轻药物毒性, 使用药更加安全 可靠. 很多古籍如《本草蒙鉒》《本草易读》《得配本 草》等都有 “何首乌以获苓为使”的记载, 但是现代临 床应用过程中何首乌却鲜有配伍获苓使用, 2013年 CFDA提示关注肝损伤风险的 5 个含何首乌的制剂(养 血生发胶囊、首乌丸、首乌片、首乌延寿片、首乌延 寿颗粒)皆没有与获苓配伍使用. 课题组从动物水平 和细胞水平研究何首乌与茯苓或甘草配伍减毒作用, 结果显示获苓配伍减毒效果最好 ${ }^{[29]}$. 对大鼠血浆生 化指标, 细胞因子检测, RT-qPCR及肝组织免疫组化 的结果进行综合分析, 何首乌确实能够增强免疫应 激状态大鼠的肝损伤作用, 配伍获苓能够起到减毒 效果, 且比例为 $1: 2$ 时减毒效果最佳 ${ }^{[30]}$. 依据中医对 制首乌性滋淢的认识，长期服用也会导致湿邪困脾、 脾胃功能受损, 而肝脏大抵属于中医的脾胃范畴, 因 此如果不对证用药, 首乌可能导致脾胃(肝脏)受损. 从中医的角度来看, 配伍白术、获苓之类的健脾祛湿 类中药, 则可以避免或降低脾胃(肝脏)受损.

\section{3 基于辨证(病)用药减毒的何首乌肝毒性评价 及合理用药}

“有毒”“无毒”其实是一个相对的概念, 中医药辨 证论治的准确与否是导致药物作用向“效”或“毒”转 化的重要条件. 用药对证, 则“毒”药也可发挥治疗作 用; 而药证相反, 则往往容易出现毒副作用. 因此, 应高度重视中医“辨证(病)用药减毒”对中药安全合理 用药的指导价值. 现在临床上很多服用首乌出现肝 损伤的患者都是自行在药店购买服用何首乌, 没有 在中医指导下辨证用药; 并且很多患者没有把何首 
乌当作药品来使用, 而是当作延年益寿的保健品, 认 为无论是有病还是无病都可以服用, 且存在超剂量 长期服药的问题, 无疑增大了发生毒副反应的风险.

“辨证(病)用药减毒”在中医药的应用实例很多, 像传统有毒中药附子, 火神派医家超大剂量安全使 用附子, 特别是在救治心衰等危重症和肿瘤等疑难 病症时取得良好的临床疗效; 砒霜是公认的剧毒药, 但是三氧化二砷注射液已成功用于白血病及各类癌 症的治疗. 大黄安全性评价研究, 结果发现正常生理 状态和病理状态的动物对大黄肝毒性的应答是不同 的, 多次重复实验显示, 肝损伤模型动物对大黄的耐 受性显著提高, 为正常动物的 2 4倍; 在正常动物出 现肝毒性的剂量, 反而对肝炎模型动物具有良好的 保护作用 ${ }^{[21,31,32]}$. 大黄在肾损伤动物也可看到此类现 象 $^{[33]}$. 实际上这与古书《素问 - 六元正纪大论》中记 载的 “有故无殒”思想相吻合, 即: “黄帝问曰妇人重 身, 毒之何如? 岐伯曰: 有故无殒, 亦无殒也. 帝曰: 愿闻其故何谓也? 岐伯曰: 大聚大积, 其可犯也, 衰 其大半而止, 过者死”. “有故无殒”通俗地讲就是“有 病则病当之, 无病则体受之”.

CFDA在制定监管何首乌肝损伤风险措施过程 中发现, 约 500 种含何首乌中药制剂中有 15 种是用于 治疗慢性肝病的, 既然何首乌有导致肝损伤风险, 这 些制剂是否可以用于慢性肝病治疗, 如何加以监管, 这些问题尚无科学数据支撑. 值得注意的是, 这 15 种 治疗慢性肝病的制剂并没有肝损伤不良反应或加重 原有肝病的报道. 这一方面可能是基础肝病掩盖了 何首乌自身的肝损伤作用; 另一方面也可能是由于 对病(证)用药, 因而何首乌体现出的是保护和治疗作 用, 而不是损伤作用, 也就是《黄帝内经》中 “有故无 殒”的认识. 课题组研究表明何首乌存在 “有故无殒” 的现象, 使用同等剂量的何首乌, 与正常动物相比, 有“故”的机体 (慢性肝损伤和纤维化) 表现出更好的 耐受性(或敏感性降低), 这可能与慢性肝损伤和纤维 化机体对外界刺激的免疫应答模式改变相关 ${ }^{[34]}$.

\section{4 免疫应激或为何首乌致肝损伤的重要诱 因之一}

\section{1 “免疫应激介导何首乌特异质肝损伤假说”的 提出}

根据课题组前期临床流行病学调研结果, 发现
何首乌肝损伤属于低概率事件, 具有特异质属性 ${ }^{[5]}$. 统计发现, 白发病、湿疹、白瘕风、骨关节病、银屑 病、系统性红斑狼疮等与免疫相关的基础性疾病的患 者服用何首乌出现肝损伤的几率相对较高, 这些患

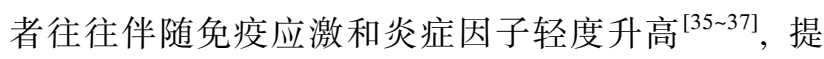
示具有这些基础疾病的患者体质可能属于免疫应激 状态; 结合免疫因素在药物特异质肝损伤中的重要 影响作用 ${ }^{[38]}$, 提示免疫应激可能是何首乌特异质肝 损伤的重要诱因之一. 基于上述考虑, 课题组提出 “免疫应激介导何首乌特异质肝损伤”的假说：当机 体的基础免疫处于较高水平时, 何首乌中的免疫增 强物质可能会导致肝脏对何首乌中潜在的肝损伤成 分的易感性增强, 出现炎症因子过表达, 从而诱发免 疫应激肝损伤 ${ }^{[39]}$.

\section{2 实验证实免疫应激介导何首乌特异质肝损伤 的客观真实性}

针对免疫应激可能是何首乌特异质肝损伤诱因 的认识, 课题组采用国际上广泛使用的免疫应激介 导的特异质药物肝损伤动物模型, 考察何首乌特异 质肝损伤的客观性. 结果表明, 在正常大鼠上单次灌 胃给药超大剂量生何首乌 $50 \%$ 乙醇提取物 (75.6 g生 药 $/ \mathrm{kg}$, 相当于临床常用剂量 $12 \mathrm{~g}$ 的 70 倍)也未见明显 肝损伤作用，与文献报道结果一致，表明何首乌对正 常动物的肝毒性不强; 而在内毒素(尾静脉注射LPS $2.8 \mathrm{mg} / \mathrm{kg}$ ) 制备的免疫应激大鼠模型上, 何首乌醇提 物单次灌胃给药在1.08 75.6 $\mathrm{g}$ 生药 $/ \mathrm{kg}$ 的范围内均出 现显著的肝功能损伤 (均 $P<0.05)$, 肝脏组织切片可见 明显病理学改变, 且表现出一定的量-毒关系, 最低 中毒剂量相当于临床常用剂量 $12 \mathrm{~g} / \mathrm{日}^{[40]}$, 病理、毒理 学特征与文献报道的药物特异质肝损伤结果相 似 ${ }^{[41 ~ 43]}$. 基于免疫应激状态的何首乌特异质肝损伤 相关物质研究表明二苯乙烯苷构象变化与何首乌特 异质肝损伤密切相关.

进一步采用采用Luminex细胞因子检测芯片对 大鼠肝组织与血浆中细胞因子进行篮查. 结果表明, 内毒素介导的炎症模型可以模拟免疫应激状态, 表 现为细胞因子轻度上调, 可以引起温和的、无损伤或 者轻微损伤的免疫炎症反应, 但是表达上调量不足 以引起肝损伤，再给药何首乌后引起TLR4-NF-KB等 信号通路的活化、炎症细胞分化和激活、诱导 TNF- $\alpha$ 、 IL-1 $\beta$ 、IL-6、MIP-2、MCP-1等炎症因子和趋化因子 
释放, 组织内环境稳定性破坏, 使肝脏对药物敏感性 大大增强, 表现出药物特异质肝损伤. 基因芯片初步 研究结果与上述免疫应激介导的细胞因子篮选结果 一致, 综合提示免疫应激可能是何首乌特异质肝损 伤的重要诱因. 研究结果对指导临床从免疫应激角 度笁选何首乌肝损伤易感人群和生物标志物, 避免 易感人群用药引起的肝损伤风险, 解决何首乌肝损 伤问题有重要参考价值 ${ }^{[39]}$.

\section{5 何首乌合理用药与风险控制的建议}

根据上面分析可以看出, 何首乌致肝损伤的影 响因素很多, 主要原因可以概括为两方面: 一是药的 原因, 如炮制不规范、存在配伍禁忌、药材质量问题 等; 二是人的原因, 如存在特异质人群(易感人群), 没有按照中医辨证用药, 患者自行超大剂量长期服 用等. 针对上述原因, 结合我国医药管理部门新颁布 的监管办法, 提出几点何首乌合理用药研究与风险 控制建议:

（1）加强基原鉴别: 根据《中国药典》, 苶科植物 何首乌Polygonum multiflorum Thunb. 为何首乌唯一 的基原, 但目前市场上仍存在混伪品、炒作的现象, 如“雌雄何首乌”、“人形何首乌”, 有的是伪品, 有的 是商家自行加工制作进行炒作, 安全性难以保证, 应 加强基原鉴别.

（2）建议保健食品中使用制首乌，不使用生首 乌: 从本草文献和现代研究可以看出, 生首乌性味、功 能主治和保健功能关系不密切, 而且生首乌有小毒, 出现肝损伤的几率较制首乌高; 制首乌经炮制后, 去 小毒滋补作用增强, 因此建议生首乌不列入保健食 品名单. 制首乌作为保健食品应限用剂量, 参考 2014 年国家食品药品监督管理总局规定标准: 制何首乌 每日用量不得超过3.0 g (http://www.sda.gov.cn/WS01/ CL0847/102806.html).

(3) 有 6 种含何首乌制剂不作为 OTC药品使用, 在产品说明书中增加何首乌临床用药注意事项(http:// www.sda.gov.cn/WS01/CL0844/93676.html), 如何首 乌不适用于大便溏泄及有湿痰的患者; 忌与天雄、乌 头、附子、仙茅、姜、桂等诸燥热药同用; 服食忌诸 血、无鳞鱼、萝卜、葱、蒜等; 不宜与含铁的药品一 同服用，煎煮何首乌时忌用铁器.

（4）建议加强制首乌原料的质量控制：完善和制 订何首乌炮制减毒规范, 增加减毒效果评控方法和
指标(如肝细胞毒价检测).

（5）开展何首乌肝损伤易感人群及其生物医学 特征和标志物篮选研究, 建立易感人群篮查和早期 诊断方法，避免易感人群用药，降低出现毒副反应的 风险.

（6）构建基于整合证据链的中药肝损伤客观诊 断方法和标准, 提高中药致肝损伤的临床诊断客观 性和准确性.

（7）构建符合中医药特点和的合理制用技术体 系，提高临床用药风险控制水平.

\section{6 结语和展望}

近年来, 有关中药肝毒性报道不断增多, 尤其是 以何首乌的肝毒性问题成为與论热点. 中药肝毒性 的问题严重影响着中医药声誉和信任度, 已成为制 约中药临床疗效发挥、安全用药和学科发展的关键瓶 颈问题. 由于缺少特异性诊断指标，药物性肝病确诊 和致病药源的确定非常困难, 由于中药组成和用药 的复杂性，确诊中药肝损伤更加困难. 由于目前没有 专门针对中草药肝损伤复杂性特点的诊断的方法及 标准，临床上存在中药肝损伤诊断不够客观准确、混 淆不良反应和不良反应事件区别、夸大中药毒性的现 象和问题, 既误导了公众, 又影响了研究的科学严肃 性. 为此, 建立基于整合证据链的中药肝损伤客观辨 识模式和方法, 有助于科学客观地评价中药肝损伤 发生率, 发现可能的损肝中药及易感人群, 为中药肝 毒性的科学评价与研究提供客观前提和研究方向. 目前，《中草药相关肝损伤临床诊疗指南》即将由中 华中医药学会发布, 填补中药肝损伤临床诊断方法 和标准的空白.

影响何首乌安全用药的因素众多, 既有药的因 素, 也有人的因素. 对药, 应加强炮制减毒、配伍减 毒、辨证药用减毒, 建立能够反映毒性大小的饮片质 量控制方法和标准，降低用药风险; 对人，应避免不 对证用药和易感人群用药，因此下一步研究方向应 重点放在篎查何首乌肝损伤易感人群的体质、基础疾 病和药物代谢酶等生物医学特征, 寻找何首乌肝损伤 的外源性成分和内源性生物标志物, 建立快速灵敏且 特异性好的早期诊断方法和指标, 避免何首乌用药风 险. 2015年初, 美国启动“精准医学研究计划”, 其核心 思想和目标是实现因人因病而异的、更加精确的个体 化医疗, 这与中医药个体化诊疗理念非常相似. 因此, 
亟待建立符合中医药特点的合理用药和风险评控方 法, 为临床辨质用药、辨证用药提供科学支撑, 最后
达到精准用药, 为实现中药质控个性化、临床用药个 体化、促进中医精准医学提供一体化的解决方案.

\section{参考文献}

1 Wang J B, Xiao X X, Du X X, et al. Identification and early diagnosis for traditional Chinese medicine-induced liver injury based on translational toxicology. China J Chin Materia Medica, 2014, 39: 5-9 [王伽伯, 肖小河, 杜晓䂀, 等. 基于转化毒理学的中药肝损害客 观辨识与早期诊断. 中国中药杂志, 2014, 39: 5-9]

2 Hoofnagle, J H, Serrano J, Knoben J E, et al. LiverTox: a website on drug-induced liver injury. Hepatology, 2013, 57: 873

3 Danan G, Benichou C. Causality assessment of adverse reactions to drugs-I. A novel method based on the conclusions of international consensus meetings: application to drug-induced liver injuries. J Clin Epidemiol, 1993, 46: 1323-1330

4 Chalasani N P, Hayashi P H, Bonkovsky H L, et al. Practice Parameters Committee of the American College of Gastroenterology. ACG Clinical Guideline: the diagnosis and management of idiosyncratic drug-induced liver injury. Am J Gastroenterol, 2014, 109: 950-966; 967

5 Zhu Y. The clinical characteristics and treatment of drug-induced liver injury. Doctor Dissertation. Beijing: Academy of Military Medical Sciences, 2012 [朱云. 药物性肝损伤临床特征及治疗预后分析. 博士学位论文. 北京: 军事医学科学院, 2012]

6 Zhu Y, Li Y G, Wang Y, et al. Analysis of clinical characteristics in 595 patients with herb-induced liver Injury. Chin J Integ Tradit West Med, 2016, 36: 44-48 [朱云, 李永纲, 王葽, 等. 595 例中药导致肝损伤临床特征分析. 中国中西医结合杂志, 2016, 36:44-48]

7 Navarro V J, Lucena M I. Hepatotoxicity induced by herbal and dietary supplements. Semin Liver Dis, 2014, 34: 172-193

8 Teschke R, Frenzel C, Glass X, et al. Herbal hepatotoxicity: a critical review. Br J Clin Pharmacol, 2013, 75: 630-636

9 Wang J B, Ma Z J, Niu M, et al. Evidence Chain-Based Causality Identification for Herb-induced Liver Injury: Exemplification of a Famous Liver-restorative Herb Polygonum Multiflorum. Front of Med, 2015, 9: 457-467

10 Liu M M, Pan L L, Wei Y T, et al. Liver damage induced by Polygonum Multiflorum powder: a report of 2 cases. J Clin Hepatol, 2015, 31: 110-111 [刘苗苗, 潘留兰, 魏玉统, 等. 服用何首乌粉致肝损害 2 例报告. 临床肝胆病杂志, 2015, 31: 110-111]

11 Zhang Y, Chen S, Lu L. Clinical analysis of 36 cases of drug-induced liver injury by Polygonum Multiflorum Thunb. Hainan Med J, 2013, 24: 235-237 [卢涛, 张陈. 何首乌致肝损伤 36 例临床分析. 海南医学, 2013, 24: 235-237]

12 Wang X M, Zhang P, Wang L. Reason analysis of 36 cases of drug-induced liver injury by Polygonum multiflorum Thunb. BJ J Tradit Chin Med, 2014, 39: 699-701 [王晓萌, 张鹏, 王林. 38 例何首乌致肝损害的原因分析. 北京中草药, 2014, 39: 699-701]

13 But P P, Tomlinson B, Lee K L. Hepatitis related to the Chinese medicine Shou-wu-pian manufactured from Polygonum Multiflorum. Vet Human Toxicol, 1996, 8: 280-282

14 Jung K A, Min H J, Yoo S S, et al. Drug-induced liver injury: Twenty five cases of acute hepatitis following ingestion of Polygonum Multiflorum Thunb. Gut Liver, 2011, 5: 493-499

15 Park G J, Mann S P, Ngu M C. Acute hepatitis induced by ShouWu-Pian, a herbal product derived from Polygonum Multiflorum. J Gastroenterol Hepatol, 2001, 16: 115-117

16 Mazzanti G, Batinelli L, Daniele C, et al. New case of acute hepatitis following the consumption of Shou Wu Pian, a Chinese herbal product derived from Polygonum Multiflorum. Ann Int Med, 2004, 140: W30

17 Panis B, Wong D R, Hooymans P M, et al. Recurrent toxic hepatitis in a Caucasian girl related to the use of Shou Wu Pian, a Chinese herbal preparation. J Pediatr Gastroenterol Nutr, 2005, 41: 256-258

18 Cárdenas A, Restrepo J C, Sierra F, et al. Acute hepatitis due to shen-min: A herbal product derived from Polygonum Multiflorum. J Clin Gastroenterol, 2006, 40: 629-632

19 Min H J, Jung K A, Kim H J, et al. Twelve cases of toxic hepatitis related to the root of Polygonum Multiflorum Thunb. J Hepatol, 2008, 47: S356

20 Zhu Y, Liu S H, Wang J B, et al. Clinical analysis of drug-induced liver injury caused by Polygonum Multiflorum and its preparations. Chin J Integ Tradit West Med, 2015, 35: 1442-1447 [朱云, 刘树红, 王伽伯, 等. 何首乌及其制剂导致药物性肝损伤的临床分析. 中 国中西医结合杂志, 2015, 35: 1442-1447]

21 Wang J B, Zhao H P, Zhao Y L, et al. Hepatotoxicity or hepatoprotection? Pattern recognition for the paradoxical effect of the Chinese herb Rheum palmatum L. in treating rat liver injury. PLoS One, 2011, 6: e24498

22 Cui H R, Wang J B, Song H B, et al. Hepatoxic factors investigation of fleece-flower root: from the ancient processing method to the modern, China J Chin Materia Medica, 2016, 41: 333-339 [崔鹤蓉, 柏兆方, 宋海波, 等. 从古今炮制方法演变探讨何首乌毒性的潜 在影响因素. 中国中药杂志, 2016, 41: 333-339] 
23 Li X F, Li N, Tu C, et al. Comparison of crude and prepared Polygonum Multiflorum-induced idiosyncratic hepatotoxicity based on lipopolysaccharide model. Chin Tradit Herb Drugs, 2015, 46: 1481-1486 [李晓菲, 李娜, 涂灿, 等. 基于内毒素特异质模型的生首乌与制 首乌肝毒性比较研究. 中草药, 2015, 46: 1481-1486]

24 Long X C, Ma Y Y. The Trade Guidebook for Traditional Chinese Medicine in China. Beijing: People's Medical Publishing House, 2010 [龙兴超，马逾英. 全国中药材购销指南. 北京：人民卫生出版社, 2010]

25 Rao W W, Jiang L, Zhao C Y. Identification of chemical industry dyes in adulteration of Chinese medicinal materials. Chin J pharm Anal. 2007, 17: 1742-1745 [饶伟文, 蒋玲, 赵纯玉. 几种染色掺假中药的化工染料鉴定. 药物分析杂志, 2007, 17: 1742-1745]

26 Pang J Y, Wang J B, Ma Z J, et al. Quality evaluation and control of Polygoni Multiflori Radix based on chemical fingerprint and toxicity monitoring. Chin Tradit Herb Drugs, 2014, 45: 3392-3396 [庞晶瑶, 王伽伯, 马致洁, 等. 基于化学指纹图谱和生物毒性检测的何首 乌质量评控. 中草药, 2014, 45: 3392-3396]

27 Lv Y. Investigation of the quality control method for Polygoni Multiflori Radix based on L02 cell toxic potency. Master Dissertation. Beijing: Beijing University of Chemical Technology, 2010 [吕旸. 基于肝细胞毒价检测的何首乌质量控制方法研究. 硕士学位论文. 北 京: 北京化工大学, 2010]

28 Li R Y, Feng W W, Li X F, et al. Influence of metal ions on stability of 2,3,5,4'-tetrahydroxy stilbene-2-O- $\beta$-D-glucoside contained in Polygoni Multiflori Radix. Acta Pharmaceutica Sinica, 2016, 51: 116-121 [李瑞煜, 冯五文, 李晓菲，等. 金属离子对何首乌中二苯乙 烯苷稳定性的影响. 药学学报, 2016, 51: 116-121]

29 Pang J Y, Li Y M, Bai Z F, et al. Compatibility attenuated detoxification study on Radix Polygoni Multiflori-caused hepatic sinus endothelial cell injury based on high content analysis. Modern Chinese Medicine, 2015, 17: 331-334 [庞晶瑶，李雨萌，柏兆方，等. 基于高 内涵分析的何首乌对肝窦内皮细胞损伤的配伍减毒研究. 中国现代中药, 2015, 17: 331-334]

30 Pang J Y. Preliminary study to attenuate the toxicity of Heshouwu by differentiating disease status and drug combination. Master Dissertation. Beijing: Capital Medical University, 2012 [庞晶瑶. 何首乌辨病用药和配伍减毒的初步研究. 硕士学位论. 北京: 首都医科大学, 2012]

31 Qin L S, Zhao H P, Zhao Y L, et al. Protection and bidirectional effect of rhubarb anthraquinone and tannins for rats' liver. Chin J Integ Tradit West Med, 2014, 34: 698-703 [覃鲁珊，赵海平，赵艳玲，等. 大黄葱醌与鞣质对大鼠肝脏的保护和损伤双向作用. 中国中西 医结合杂志, 2014, 34: 698-703]

32 Wang Y H, Zhao H P, Wang J B, et al. Study on dosage-toxicity /efficacy relationship of prepared rhubarb on basis of symptom-based prescription theory. China J Chin Materia Medica, 2014, 15: 026 [王艳辉，赵海平，王伽伯，等. 基于 “有故无殒” 思想的熟大黄对肝 脏量-毒/效关系研究. 中国中药杂志, 2014, 15: 26]

33 Zeng L N, Ma Z J, Zhao Y L, et al. The protective and toxic effects of rhubarb tannins and anthraquinones in treating hexavalent chromium-injured rats: the Yin/Yang actions of rhubarb. J Hazard Mat, 2013, 246-247: 1-9

34 Pang J Y, Bai Z F, Niu M, et al. The toxic and protective effects of Polygonum Multiflorum on normal and liver injured rats based on the symptom-based prescription theory. Acta Pharmaceutica Sinica, 2015, 50:973-979 [庞晶瑶, 柏兆方，牛明，等. 基于“有故无殒”的何 首乌对正常和肝损伤大鼠的毒性与保护作用对比研究. 药学学报, 2015, 50: 973-979]

35 Gu J S, Tu C X, Tan X J, et al. Serum Level of Interleukin, Tumor Necrosis Factor Alpha and Granulocyte Macrophage-Colony Stimulating Factor in Patients with Vitiligo. Chin J Dermatol, 2003, 36: 73-75 [顾劲松，涂彩霞，谭雪晶，等. 白癜风患者血清白介素、肿瘤坏 死因子 $\alpha$ 及粒细胞-巨噬细胞集落刺激因子检测。中华皮肤科杂志, 2003, 36: 73-75]

36 Ripley B J, Goncalves B, Isenberg D A, et al. Raised levels of interleukin 6 in systemic lupus erythematosus correlate with anaemia. Ann Rheum Dis, 2005, 64: 849-853

37 Singh S, Singh U, Pandey S S. Serum concentration of IL-6, IL-2, TNF- $\alpha$, and IFN $\gamma$ in Vitiligo patients. Ind J Dermatol, 2012, 57: 12-14

38 Roth R A, Ganey P E. Animal models of idiosyncratic drug-induced liver injury-current status. Crit Rev Toxicol,2011, 41: 723-739

39 Li C Y. The primary research on immunological stress-mediated idiosyncratic liver injury of Polygonum Multiflorum. Doctor Dissertation. Chengdu: Chengdu University of TCM, 2012 [李春雨. 基于免疫应激的何首乌特异质肝损伤的初步研究. 博士学位论文. 成都: 成 都中医药大学, 2012]

40 Li C Y, Li X F, Tu C, et al. The idiosyncratic hepatotoxicity of Polygonum Multiflorum based on endotoxin model. Acta Pharmaceutica Sinica ,2015, 50:28-33 [李春雨, 李晓菲, 涂灿, 等. 基于内毒素模型的何首乌特异质肝损伤评价. 药学学报. 2015, 50: 28-33]

41 Waring J F, Liguori M J, Luyendyk J P, et al. Microarray analysis of lipopolysaccharide potentiation of trovafloxacin induced liver injury in rats suggests a role for proinflammatory chemokines and neutrophils. J Pharmacol Exp Ther, 2006, 16: 1080-1087

42 Luyendyk J P, Lehman-McKeeman L D, Nelson D M, et al. Coagulation-dependent gene expression and liver injury in rats given lipopolysaccharide with ranitidine but not with famotidine. J Pharmacol Exp Ther, 2006, 317: 635-643

43 Deng X, Stachlewitz R F, Liguori M J, et al. Modest inflammation enhances diclofenac hepatotoxicity in rats: Role of neutrophils and bacterial translocation. J Pharmacol Exp Ther, 2006, 319: 1191-1199 


\title{
Integrated evidence chain-based identification of Chinese herbal medicine-induced hepatotoxicity and rational usage: Exemplification by Polygonum Multiflorum (He shou wu)
}

\author{
WANG JiaBo ${ }^{1}$, LI ChunYu ${ }^{1,2}$, ZHU Yun ${ }^{4}$, SONG HaiBo $^{3}$, BAI ZhaoFang $^{1} \&$ XIAO XiaoHe ${ }^{4}$ \\ ${ }^{1}$ China Military Institute of Chinese Medicine, 302 Military Hospital, Beijing 100039, China; \\ ${ }^{2}$ Institute of Medicinal Plant Development, Chinese Academy of Medical Sciences \& Peking Union Medical College, Beijing 100193, China; \\ ${ }^{3}$ Center for Drug Reevaluation, SFDA, Beijing 100045, China; \\ ${ }^{4}$ Integrative Medicine Center, 302 Military Hospital, Beijing 100039, China
}

Toxicity and adverse drug reactions (events) related to Chinese herbal medicines (CHMs) have been reported increasingly and stirred discussion within the public, media, government and academia, of which hepatotoxicity has become prominent problems in recent years, especially for those CHMs not conventionally considered of toxicity, for instance, Polygonum Multiflorum Thunb. (He shou wu in Chinese). Nowadays, clinical diagnosis for drug-induced liver injury (DILI) mainly adopts the Roussel Uclaf Causality Assessment Method (RUCAM) and the structured expert opinion process (SEOP). However, the accurate diagnosis of DILI is still the international challenge due to a lack of specific diagnosis indicators. Herb-induced liver injury (HILI), nevertheless, is more difficult to diagnosis and sometimes exists misdiagnosis, by reason of the complexity of both the composition of CHMs and combinational prescription of CHMs and western medicines in clinic.

At present, there is still a lack of objective diagnosis methods and standards for HILI according with the characteristics of CHMs, which has enormously restricted the scientific research and safe uses of CHMs. In this paper, He shou wu was chosen as an example to discuss the objective authenticity and the influencing factors of HILI, as well as the problems reflected in toxicity identification, risk assessment and rational use of CHMs. With the clinical objective evidence as the core, the innovative research was carried on in two aspects of the clinical diagnosis method and risk controlling strategy. Firstly, the integrated evidence chain-based identification strategy and method for HILI was proposed by reference to clinical indices, medication history, pharmacognosy and potential biomarkers of HILI, in order to construct integrated evidence chain and then improve the veracity and reliability of HILI diagnosis. The more complete integration of evidence chain makes the higher reliability of the HILI diagnosis. Furthermore, the immune stress mechanism was put forward to explain He shou wu-induced idiosyncratic liver injury, and the objective authenticity of such mechanism was proved in the experiment. From the perspective of immunological stress, such mechanism would guide clinical screening potential biomarkers in susceptible population of He shou wu-induced idiosyncratic liver injury to avoid its risk of liver injury. Secondly, the CHM characteristic-oriented toxicity attenuating and rational use strategy was proposed for systematic research of susceptible population screening, processing-driven toxicity attenuating, drug combination-driven toxicity attenuating and syndrome differentiation-driven toxicity attenuating (meanings of the ancient theory-YOU GU WU YUN recorded in CHM classics). The previous research results demonstrated that processing would significant attenuate the idiosyncratic liver injury of He shou wu. And it was found that ferric ions would significantly enhance the hepatotoxicity of He shou wu in processing or preserving progress. The above mentioned strategy would construct for the scientific evaluation of CHMs related liver injury risk, the rational use of drugs research ideas and methodology reference for the drug safety evaluation system.

In conclusion, through the research on the integrated evidence chain-based identification strategy for HILI and the CHM characteristic-oriented toxicity attenuating and rational use strategy, it would be helpful to provide scientific support for HILI diagnosis and CHMs prescription, and finally to promote integrated solutions for personalization of quality control, individualization of clinical prescription and precision medicine of CHMs.

Chinese herbal medicine, Polygonum Multiflorum, hepatotoxicity, integrated evidence chain, objective identification, rational usage

doi: 10.1360/N972015-01289 